\title{
Üniversite Öğrencilerinin Film İzleme Alışkanlıklarının Covid-19 Pandemisi Sürecinde Değişiminin Belirlenmesi
}

\author{
Determining the Change of Movie Watching Habits of University Students During the Covid-19 \\ Pandemic Process
}

Gözde Sunal, Dr. Öğr. Üyesi, İstanbul Ticaret Üniversitesi İletişim Fakültesi, E-posta: gsunal@ticaret.edu.tr Seda Bă̆datlı Kalkan, Doç. Dr., İstanbul Ticaret Üniversitesi İnsan ve Toplum Bilimleri Fakültesi, E-posta: sbagdatli@ticaret.edu.tr

https://doi.org/10.47998/ikad.843067

\author{
Anahtar Kelimeler: \\ Covid-19 Pandemisi, \\ Sinema, \\ Film İzleme \\ Alışkanlıkları, \\ Dijital Platformlar, \\ Genç İzleyiciler.
}

Keywords:

Covid-19 Pandemic, Cinema,

Movie Watching Habits, Digital Platforms, Young Audiences.
$\ddot{\mathbf{O} z}$

Covid-19 ile mücadele kapsamında salgının tesirini ve yayılma hızını azaltabilmek adına uygulanan karantinalar, dünyanın her yerinde evde geçirilen zamanı artırmıştır. Bu durumda izleme alışkanlıklarımız tamamen değiştirmiştir. Covid-19 pandemisi sürecinde içerik üretemeyen televizyon kanalları seyirciye kendisinden bekleneni verememektedir. Seyircinin içinde bulunduğu ortamdan kaçış, zaman kontrolünün kendisine bırakılması, içerik seçiminde özgür olması gibi imkanlardan dolayı izleme alışkanlıkları üzerinde bir dönüşüm söz konusudur. Bu dönüşümün başlıca sebepleri olan yeni iletişim teknolojileriyle birlikte bireylerin filmlere çok daha kolay erişebilmesi, film izlemenin neredeyse maliyetsiz bir hale gelmesi, zaman ve mekan sınırlamalarının yok olması film izleme alışkanlıklarımızı, sinema salonlarının dışına kaydırarak seyirciye hem ekonomik anlamda hem de filmlere erişme de imkan tanımaktadır. Üniversitelerin pandemi sürecinde online eğitime devam etmesiyle özellikle gençlerin film izleme alışkanlıklarında değişiklik olduğu düşünülmektedir. Dolayısıyla Covid-19 pandemisi ile film izleme deneyimi dijital sinema seyircisine ve bireysel olarak deneyimlenen bir pratiğe dönüşmüștür. Evlere kapandığımız bu dönemde bireyselleşen bu deneyim domestik alanlarda oldukça ön plana çıkmaktadır. Bu noktadan hareketle çalışma, pandemi döneminde üniversite öğrencilerinin film izleme alışkanlıklarındaki değişimi ortaya çıkarmayı hedeflemektedir. Çalışma, bir vakıf üniversitesinde okuyan tüm öğrencilere dijital ortamda oluşturulan anket ile gerçekleştirilmiş ve elde edilen sonuçlar analiz edilmiştir.

\section{Abstract}

The quarantines applied to reduce the impact and the rate of spread of the epidemic within the scope of combating Covid-19 have increased the time spent at home all over the world. In this case, our watching habits have completely changed. Television channels that cannot produce content during the Covid-19 pandemic cannot give the audience what is expected of them. There is a transformation in the watching habits due to the opportunities such as escape from the environment the audience is in, the time control belongs to them, and they are free in content selection. With the new communication technologies, which are the main reasons of this transformation, individuals' access to movies much more easily, watching movies becomes almost cost-free, and the disappearance of time and space restrictions allow the audience to access movies both economically and by shifting our movie watching habits outside of movie theaters. It is thought that there has been a change in the habits of young people watching movies, as universities continue online education during the pandemic process. Therefore, the movie watching experience with the Covid-19 pandemic has become a digital cinema audience and a practice experienced individually. In this period when we are confined to homes, this individualized experience comes to the fore in domestic areas. From this point of view, the study aimed to reveal the change in movie watching habits of university students during the pandemic period. The study was conducted with a digitally created questionnaire for all students studying at a foundation university, and the results obtained were analyzed.

Araştırmacı Orcid ID

Geliș Tarihi

Kabul Tarihi 


\section{Giriș}

Yeni iletişim teknolojilerinin sağladığı birtakım imkanlarla 21. yüzyıl yeni iletişim teknolojilerinin dünyası durumuna gelmiştir. $\mathrm{Bu}$ çağ ile geleneksel medya kavramının yerini yeni medya kavramı almıştır. Yeni Medya geleneksel medyada kullanılan medya araçlarıyla birlikte yeni iletişim teknolojilerinin eklenmesiyle farklı bir boyut kazanmıştır. Yeni medya kavramı çoğu zaman dijital medya, interaktif medya ve multimedyadır. Yeni medya sadece bilgisayar teknolojine dayanan bir medya değil aynı zamanda etkileşimli bir araçtır. Bu yönüyle barındırdığı özellikleriyle 'melez' bir yapıya sahiptir (Aydın, 2019: 1168). Dolayısıyla bu yapı Marshall McLuhan'ın 'küresel köy’üne benzemektedir. McLuhan, elektronik iletişimle birlikte dünyanın aslında küçük bir topluluk olacağını ileri sürmüştür. Bu noktadan hareketle dijital çağ dünyanın birçok farklı noktasından bir araya gelen insanların istedikleri bilgiye anında ulaşabilme imkanını tanımaktadır.

"Bir sistemin temel fonksiyonun yanında bir başka sistemin özelliğini de kendi yapısına entegre ederek gerçekleştirdiği dönüşüm süreci” (Abanoz, 2017: 287) olan yöndeşme kavramıyla birlikte film ve televizyon izleme pratikleri iç içe geçmiştir. Dolayısıyla sinemanın dijital dönüşümüyle film üretim modellerinde ve film gösterimlerinde de ortaya çıkan dijital platformlar dünyada giderek popülerlik kazanmıştır. "Yeni medyalarla taşınabilirliği, çoğatılabilirliği ve birçok mecrada ya da mekanda yayınlanabilirliği ile görüntü, yurdunu terk ederek kendi deneyim biçimini inşa etmekte, hatta gündelik mekanlarda dahi seyircisini bu deneyim biçiminin bir parçası olmaya zorlamaktadır" (Oğuzhan, 2015: 210).

21. yüzyıldan itibaren başlayan dijitalleşme (sayısallaşma) aslında birçok alanı da etkisi altına almıştır. "Bu kavram son dönemde birçok alandaki gelişmelere katkıda bulunan en önemli teknolojik ilerleme olarak ele alınabilir. Sayısallaşma analog mesajların (söz, resim, mektup) nakledilebilen, işlenebilen ve elektronik olarak depolanabilen ayrı ayrı vuruşlardan oluşan sinyallere dönüştürülmesi sürecidir (Ormanl1, 2012: 32). Dijitalleşme, enformasyonun içerisinde bulunduğu analog halinden bilgisayarlar tarafından okunabilir bir formata dönüştürülmesidir (Aktaş, 2014: 59). Dijitalleşmenin etkileri sadece telekomünikasyonda değil müzik, fotoğraf, radyo, televizyon ve bilgisayar gibi tüm iletişim araçlarını sayısal hale gelmiştir (Ormanlı, 2012: 32-33).

Gelişen teknoloji ile birlikte gündelik hayat pratiklerimiz büyük bir hızla değişmektedir. Dijital yayıncılık özellikle 2010 yılı sonrasında Türkiye'de giderek yaygınlaşmaya başlamıştır. Teknik altyapının gelişmesiyle birlikte dijital yayıncılık artık farklı bir izleme alışkanlığını beraberinde getirmiştir. YouTube ile başlayan ve sonrasında devam eden abonelik sistemli video platformlar (Netflix, Puhutv, BluTV vb.) modern bireyin film izleme alışkanlıklarını değiştirmeye başlamıştır.

2020 yılı itibariyle dünya çapında büyük bir salgına neden olan daha önce insanlarda tanımlanmamış yeni bir virüs olan 'Covid-19 ilk olarak Aralık 2019'un sonunda Çin'in Hubei eyaletinde tespit edilmiştir. Virüs son derece bulaşıcıdır ve her gün dünya çapında binlerce yeni vaka rapor edilmektedir" (Özden vd., 2020). Tüm dünyanın evlerine kapandığ sağlam bir yer edinmiştir. Bu bağlamda teknolojik imkanlarla genişleyen pazar farklı dijital platformlarla seyirciye farklı deneyimle birlikte katılım da sunmaktadır. 
Tüm dünyada hızla yayılan ve video, tv ya da içerik izleme alışkanlıkları üzerinde ciddi değişikliklere neden olan dijital içerik platformları ülkemizde de geniş kitleler tarafından sıklıkla kullanılmaktadır. İnsanların serbest zaman aktivitelerinin pandemi sürecinde değişiklik gösterdiği düşünülmektedir. Günümüzde gelişen internet temelli teknolojilerle bireysel izleme imkanları daha da artmıştır. Ortaya çıkan dijital platformlar çok sayıda içeriği her gün milyonlarca izleyici ile buluşturmaktadır” (Aydın, 2019: 1172) Dijital platformların sundukları kişinin tercihine göre şekil alan kullanıcı deneyimleri gibi çeşitli avantajlar sağlamaktadır. Özellikle pandemi sürecinde zamanımızın çoğunu evde geçirdiğimiz şu günlerde online içerik sağlayıcı dijital platformlar günümüz bireyine istediği filmi, istediği zamanda, istediği yerde izleyebilme olanağı sağlamaktadır.

$\mathrm{Bu}$ noktadan hareketle, bu çalışmada üniversite öğrencilerinin film izleme alışkanlıkları üzerindeki -pandemi öncesi ve sonrası- farklılıkların ortaya koyulması amaçlanmaktadır. Çalışma bir vakıf üniversitesinin tüm fakültelerinde eğitim görmekte olan öğrencilerine yönelik anket çalışmasını kapsamaktadır. Özellikle 2020’li yıllarda yaşanan Covid-19 pandemi sürecinin gündelik hayatın tamamına yayılan film izleme deneyiminin değişimi üzerindeki etkisi ele alınacaktır. Bu doğrultuda pandemi öncesi ve sonrası olarak üniversite öğrencilerinin film izleme alışkanlıklarının değişimi üzerine bir çalışma olması hedeflenmektedir.

\section{Yeni İletişim Ortamları ile Birlikte Gelen Yeni İzleme Biçimleri}

Hızla gelişim gösteren teknolojik imkânların etkisiyle adından sıkça söz ettiren dijitalleşme, hareketli görüntü sanatında önemli bir yer tutmaktadır. Bu süreç ise, film üretim, dağıtım ve gösterim süreçlerini oldukça değiştirmiş ve film dilini büyük ölçüde etkilemiştir. Bu etki kimi zaman avantaj kimi zaman dezavantaj olarak tartışmaya açılmaktadır. Dijital sinema teknolojilerinin, önceki iletişim biçimlerine göre çok daha fazla insanla sık sık iletişime geçmeyi mümkün kılması; yapım-dağıtım aşamasının daha ucuz yollarla mümkün olmasının, iletişim alanında yarattığı avantajlarının yanı sıra bazı yönleriyle de eleştirilmeye açık bir sorunsal olduğu düşünülmektedir (Sunal, 2016: 306).

Teknolojinin gelişimi ile yeni sinema anlatısının dönüşümü Dünya sinemasında olduğu kadar Türk sinemasında da etkili olmuştur. Dünya film endüstrisi dijitalleşmenin olanaklarıyla çok önceden tanışmasına rağmen Türk sineması geç bir zamanda tanışmıştır. Tüm film üretim tekniklerinin (renk, 1şık, oyunculuk gibi) işlevi dijital teknoloji nedeniyle değişmeye başlamıştır. Bu süreç filmin üretilen gerçeklikten bağımsız bir biçimde işlenebilmesini, filmin üzerinde oynanabilmesini, 2 veya 3 boyutlu öğelerin bir araya gelerek birleşilmesini sağlamaktadır (Şentürk, 2016: 38). Türkiye'de özellikle 2003-2010 yılları arasında gözlemlenen değişimlerin film endüstrisine de yansıdığ görülmüştür. Ekonomik, politik ve kültürel alandaki dönüşümlerin elbette çeşitli sebepleri bulunmaktadır. Teknolojik ilerleyiş ile birlikte film yapım masraflarının azaltılması, bu alanda eğitim gören öğrencilerin sayısı artması, kurgu ve görüntünün dijitalleşmesi ve bu sayede ilgisi olanların denemeler yapacağı yer imkanları bulmaları, görsel kültür düzeyinin artması bu gelişmede katkısı olduğu söylenebilir (Şentürk, 2014: 135). 
Bir filmin yapım yönetim süreçleriyle birlikte gösterim ve finans seçenekleri açısından da dijitalleşme süreci yeni imkanlar sağlamaktadır. Bu yeni imkanlar sayesinde hem izleme kültürü hem de film edinme alanlarımız değişmektedir. İzleyici açısından dijital platformlar diğer alanlara göre çok daha rahat bulunmuştur bu sebeple her geçen gün Netflix, Hulu, Amazon TV gibi platformlar yaygınlaşmaya başlamaktadır. İzleyici alışkanlıkları günden güne değişerek filmler internet ya da abonelik sistemli video platformlarına taşınmaktadır.

2016 yılı itibariyle dijital yayın platformlarından Netflix'in Türkiye pazarına girişi gerçekleşmiştir. Netflix'in ardından, Doğan Medya Grubu "Blu TV" adlı platformu; Doğuş Grubu ise "Puhu TV"yi kurmuştur. Bu platformların başında ilk akla geleni ise Netflix'tir. Netflix önce bir dvd kiralama şirketi olarak başlamış sonrasında ise abonelik sistemine geçmiştir. 1997 yılında ABD'de kurulan bu dvd kiralama şirketi 2007 yılında ise online film izleme ve indirme platformu olarak kendi içinde bir dönüşüme uğramıştır (Randolph, 2020: 147).

Netflix dizileri ve filmleri laptoplardan, cep telefonlarından süre ve mekan sınırlaması olmadığından izlenebildiğinden film endüstrisinin değişimini etkilemiştir. Netflix'in bu özelliği sebebiyle böyle bir platforma rakip olarak ne bir televizyon kanalı ne de bir sinema salonu bulunmaktadır. Böylece Netflix orijinal içerikler geliştirerek geniş bir yelpazede farklı dizi ve film projelerine yer vermektedir. Abone olan seyirciler ise çok uzun tekrarlamaları ve reklamları görmeden farklı türden birçok dizi ve film izleme şans1 edinmektedirler (URL-1). Bugün tüm dünyada abonesi olan dev bir dijital yayın platformu olan Netflix kayıtlı olan abonelerin önüne izlemekte olduğu içeriklerinden dolayı beğeneceği türde diziler ve filmler sunmaktadır. Dolayısıyla Hastings'in dediği gibi "eğlenceyi ve keşfi kolay hale getirmek" esas hedef olarak görülmektedir (URL-2). 4 Mayıs 2020 tarihli Mediacom Medya Analizi ve Tüketici Davranışları Raporuna göre Netflix 2020'nin ilk çeyreğinde global olarak 15,8 milyon yeni kullanıcı kazanmıştır. Covid 19 öncesi aynı dönem için Netflix'in öngörüsü 7 milyon yeni kullanıcıydı (Kantar Media, Mayıs, 2020: 12). Evde geçirilen sürenin artmasıyla abonelik sistemli video platformlarının artışı da raporlara yansımaktadır (Kantar Media, Nisan 2020: 9).

Puhu TV ise 2016 yılında Doğuş Yayın Grubu tarafından kurulmuştur. Bu platform seyircinin istediği zaman ücretsiz olarak izlemesini sağlayan ürün yerleştirme yöntemiyle finanse edilen bir platformdur. Örneğin, dizide rol alan oyuncuların giydikleri kıyafetler, yenilen ürünler, binilen arabalar dizinin ya da filmin anlatısına dahil edilerek kullanılmaktadır (Çağıl ve Kara, 2019: 12). Doğan Holding tarafından kurulan BluTv başka bir dijital yayın platformudur. Netflix'e rakip olmak için kurulan platform, film endüstrisi üretim süreçlerini etkilemiştir.

YouTube üzerinden ise birçok dizi yayınlanmıştır. "BluTV ve Puhu TV oluşumlarından önce ilk orjinal yerli içerik üretimi YouTube üzerinden olmuştur. Özellikle 2013 sonrasında YouTube üzerinden yayınlanan pek çok internet dizisi mevcuttur" (Çağıl ve Kara, 2019: 11). Youtube sayesinde birçok amatör film yapımcıs1 film üreterek filmlerini paylaşma imkanı bulmuşlardır. Film yapım sürecinin değiştiği gibi izlenme ortamları da değişmiştir. Bir film yapımcısı hiçbir bedel ödemeden filmini 
platforma yükleyip kendine seyirci bulabilme imkanına sahip olmaktadır. Filmini kaç kişinin izlediğini ve film hakkında yorumlara kolayca erişebilmektedir. Bu durum, sadece amatör film yapımcılarını değil aynı zamanda profesyonel film yapımcılarının ilgisini çekmiş ve onları harekete geçirmiştir. Bu noktadan hareketle profesyonel yapımcıların üretim maliyetinin azaldığını görmesi ve seyirci sayısının fazlalığ1 sebebiyle karlılığ artıran bu yöntem dikkat çekmiştir (Künüçen ve Olguntürk, 2016: 134).

2019'un son haftalarında dünyayı etkisi altına alan yeni tip corona virus salgınıyla yaşanan pandemi sürecinde boş kalan sinema salonlarının ciddi bir tehlikeyle karşı karşıya kaldığı görülmektedir. Dolayısıyla dijital platformların kendi dinamikleri ve pratikleri sayesinde film endüstrisinin yapım dağıtım ve gösterim süreçleri yeni bir anlatım dili oluştuğu düşünülmektedir.

\section{Üniversite Öğrencilerinin Film İzleme Alışkanlıklarının Covid-19 Pandemisi Sürecinde Değişimi Üzerine Bir Analiz}

\section{Araştırmanın Yöntemi}

$\mathrm{Bu}$ çalışma, bir vakıf üniversitesinde okuyan tüm öğrencileri kapsamaktadır. Veri toplama tekniği olarak anket yöntemi tercih edilmiştir. Dijital ortamda oluşturulan anket e-mail yoluyla üniversitenin tüm öğrencilerine gönderilmiştir. Örnekleme yöntemi olarak olasılıksal olmayan örnekleme yöntemlerinden keyfi örnekleme tekniği kullanılmıştır. Olasılıksal olmayan örnekleme yöntemleri, özellikle bu çalışma gibi sosyal bilimlerde yapılan araştırmalarda araştırmada yer alacak birimlerle ilgili daha ayrıntılı bilgiye sahip olmak istendiğinde kullanılmaktadır. Ayrıca, bu çalışmada olduğu gibi özellikle tanımlayıcı istatistiklere ihtiyaç duyulduğunda ve elde edilen sonuçların anakütleye belirli bir güvenilirlikle genellenmesine ihtiyaç duyulmadığında olasılıksal olmayan örnekleme yöntemleri olasılıksal örnekleme yöntemlerine tercih edilmektedir (Özdemir, Şahin Tekin, \& Esin, 2019, s. 22).

\section{Bulguların Değerlendirilmesi ve Analizi}

Bir vakıf üniversitesinde okuyan tüm öğrencilere anket gönderilmiş ve 500 anket cevaplanmıştır. $\mathrm{Bu}$ anketlerin içerisinden 445 anket analize uygun bulunmuştur. Tablo 1 'de üniversite öğrencilerine ait demografik bilgiler gösterilmektedir.

Tablo 1. Üniversite Öğrencilerinin Demografik Bilgileri

\begin{tabular}{|l|l|l|l|}
\hline \multirow{3}{*}{ Cinsiyet } & & Frekans & Yüzde \\
\hline \multirow{3}{*}{ Yaş } & Kadın & 249 & 56 \\
\cline { 2 - 4 } & Erkek & 196 & 44 \\
\hline \multirow{4}{*}{ Sinıf } & $18-24$ & 384 & 86,3 \\
\cline { 2 - 4 } & $25-34$ & 47 & 10,6 \\
\cline { 2 - 4 } & 35 ve üzeri & 14 & 3,1 \\
\hline & Birinci Sınıf & 90 & 20,2 \\
\cline { 2 - 4 } & İkinci Sinıf & 128 & 28,8 \\
\cline { 2 - 4 } & Üçüncü Sınıf & 105 & 23,6 \\
\cline { 2 - 4 } & Dördüncü Sınıf & 122 & 27,4 \\
\hline
\end{tabular}


Tablo 1'de görüldüğü üzere öğrencilerin \%56's1 kadın, \%44'ü erkektir. Yaş dağılımına bakıldığında üniversite öğrencilerine anket uyğulandığından öğrencilerin \%86,3'ü 18-24 yaş aralığında bulunmaktadır. Öğrencilerin sınıf dağılımları incelendiğinde, \%20,2'si birinci sınıf, \%28,8'i ikinci sınıf, \%23,6's1 üçüncü sınıf ve \%27,4'ü dördüncü sinıfta okumaktadır.

Ankette öğrencilere, televizyon veya tüm dijital platformları düşündüklerin de en çok seyrettikleri program türleri sorulmuştur. Televizyon'da birinci seçenek olarak $\% 52$ ile sinema filmleri ve \%20,7 ile haberler seyredilmektedir. İkinci seçenek olarak ise $\% 29,2$ ile diziler ve \%19,3 ile eğlence/güldürü programları tercih edilmektedir. Dijital platformlarda ise birinci seçenek olarak, $\% 79,8$ ile sinema filmleri ve $\% 7,2$ ile belgeseller seyredilmektedir. İkinci seçenek olarak ise $\% 57,5$ ile diziler ve $\% 11,5$ ile eğlence/güldürü programları tercih edilmektedir. Öğrencilerin bu sorulara verdikleri cevaplar arasında sinema filmleri yoksa anketi bitirmeleri istenmiştir. Ankete devam eden 370 öğrenci olmuştur. Bu öğrencilerin yaş, cinsiyet ve sınıf dağılımları tekrar incelenmiş ve sonuçlar Tablo 2'de gösterilmiştir.

Tablo 2. Sinema Filmi İzleyen Öğrencilere ait Demografik Bilgiler

\begin{tabular}{|l|l|l|l|}
\hline Değişkenler & & Frekans & Yüzde \\
\hline \multirow{3}{*}{ Cinsiyet } & Kadın & 220 & 59,5 \\
\cline { 2 - 4 } & Erkek & 150 & 40,5 \\
\hline \multirow{3}{*}{ Yaş } & $18-24$ & 322 & 87 \\
\cline { 2 - 4 } & $25-34$ & 38 & 10,3 \\
\cline { 2 - 4 } & 35 ve üzeri & 10 & 2,7 \\
\hline \multirow{4}{*}{ Sınıf } & Birinci Sınıf & 73 & 19,7 \\
\cline { 2 - 4 } & İkinci Sınıf & 108 & 29,2 \\
\cline { 2 - 4 } & Üçüncü Sınıf & 82 & 22,2 \\
\cline { 2 - 4 } & Dördüncü Sınıf & 107 & 28,9 \\
\hline
\end{tabular}

Tablo 2 incelendiğinde, ankete devam edenlerin \%59,5'i kadın, \%40,5'i erkek olduğu görülmektedir. Yaş dağımları incelendiğinde, \%87'sinin 18-24 yaş aralığındadır. Sınıf dağılımları incelendiğinde ise yüzdelerin birbirine çok yakın olduğu ancak en çok katılımın \%28,9 ile dördüncü sınıf öğrencilerinden olduğu belirlenmiştir. Sinema filmi izleyen öğrencilerin yüzdesel dağılımları, ankete katılım gösteren tüm öğrencilerin yüzdesel dağılımı ile paralellik göstermektedir.

Öğrencilerin pandemi öncesinde en çok seyretmeyi sevdiği üç film türü sorulmuş ve sonuçlar Tablo 3'de gösterilmiştir. 
Tablo 3. Pandemi Öncesi Dönemde En Çok Seyretmeyi Sevdiğiniz Üç Film Türü

\begin{tabular}{|l|c|c|c|c|c|c|}
\hline & \multicolumn{2}{|c|}{ Birinci Tercih } & \multicolumn{2}{c|}{ Íkinci Tercih } & \multicolumn{2}{c|}{ Üçüncü Tercih } \\
\hline \multirow{2}{*}{ Film Türleri } & Frekans & \multicolumn{1}{|l}{ Yüzde } & Frekans & \multicolumn{1}{l}{ Yüzde } & Frekans & \multicolumn{1}{|l|}{ Yüzde } \\
\hline Aksiyon & $\mathbf{2 2 2}$ & $\mathbf{6 0 , 0}$ & 0 & 0 & 0 & 0 \\
\hline Dram & $\mathbf{8 5}$ & $\mathbf{2 3 , 0}$ & 43 & 11,6 & 0 & 0 \\
\hline Macera & 49 & 13,2 & $\mathbf{1 3 4}$ & $\mathbf{3 6 , 2}$ & 12 & 3,2 \\
\hline Suç & 12 & 3,2 & $\mathbf{6 8}$ & $\mathbf{1 8 , 4}$ & 24 & 6,5 \\
\hline Gerilim & 1 &, 3 & 47 & 12,7 & $\mathbf{8 3}$ & $\mathbf{2 2 , 4}$ \\
\hline Romantik & 1 &, 3 & 66 & 17,8 & 52 & 14,1 \\
\hline Komedi & 0 & 0 & 12 & 3,2 & $\mathbf{1 5 9}$ & $\mathbf{4 3 , 0}$ \\
\hline DiĞer & 0 & 0 & 0 & 0 & 40 & 10,8 \\
\hline
\end{tabular}

Tablo 3 incelendiğinde, Pandemi öncesi dönemde öğrencilerin birinci tercih olarak aksiyon ve dram türünü tercih ettiği görülmektedir. İkinci tercih olarak, macera ve suç, üçüncü tercih olarak da gerilim ve komedi filmlerini tercih etmektedirler.

Öğrencilerin pandemi sonrasında en çok seyretmeyi sevdiği üç film türü sorulmuş ve sonuçlar Tablo 4'de gösterilmiştir.

Tablo 4.Pandemi Sonrası Dönemde En Çok Seyretmeyi Sevdiğiniz Üç Film Türü

\begin{tabular}{|l|c|c|c|c|c|c|}
\hline & \multicolumn{2}{|c|}{ Birinci Tercih } & \multicolumn{2}{c|}{ İkinci Tercih } & \multicolumn{2}{c|}{ Üçüncü Tercih } \\
\hline Film Türleri & Frekans & \multicolumn{1}{|c|}{ Yüzde } & Frekans & Yüzde & Frekans & Yüzde \\
\hline Aksiyon & $\mathbf{2 0 5}$ & $\mathbf{5 5 , 4}$ & 0 & 0 & 0 & 0 \\
\hline Dram & $\mathbf{8 7}$ & $\mathbf{2 3 , 5}$ & 51 & 13,8 & 0 & 0 \\
\hline Macera & 54 & 14,6 & $\mathbf{1 1 1}$ & $\mathbf{3 0 , 0}$ & 10 & 2,7 \\
\hline Suç & 21 & 5,7 & 66 & 17,8 & 27 & 7,3 \\
\hline Gerilim & 2 &, 5 & 53 & 14,3 & $\mathbf{8 0}$ & $\mathbf{2 1 , 6}$ \\
\hline Romantik & 1 &, 3 & $\mathbf{8 0}$ & $\mathbf{2 1 , 6}$ & 42 & 11,4 \\
\hline Komedi & 0 & 0 & 9 & 2,4 & $\mathbf{1 7 8}$ & $\mathbf{4 8 , 1}$ \\
\hline Diğer & 0 & 0 & 0 & 0 & 33 & 8,9 \\
\hline
\end{tabular}

Tablo 3 ve Tablo 4 birlikte değerlendirildiğinde; Öğrenciler pandemi dönemi öncesinde ve sonrasında birinci tercih olarak aksiyon fimlerini ve dram filmlerini tercih etmektedir. İkinci tercih olarak pandemi öncesinde, macera ve suç konulu filmler tercih edilirken, pandemi sonrasında suç yerine romantik filmler tercih edilmiştir. Üçüncü tercih olarak ise, her iki dönemde de gerilim ve komedi filmleri bulunmaktadır. Pandemi öncesi üçüncü tercih olarak gerilim film türünü tercih edenlerin sayısı pandemi sonrası düşerken komedi filmlerini tercih edenlerin sayısının pandemi sonrası yükseldiği görülmektedir.

Öğrencilerin pandemi öncesi ve pandemi sonrası film izlemeyi tercih ettiği günler sorulmuş ve sonuçlar Tablo 5'de gösterilmiştir. 
Tablo 5. Film İzlemeyi Tercih Edilen Günler

\begin{tabular}{|c|c|c|c|c|}
\hline & \multicolumn{2}{|c|}{ Pandemi Öncesi } & \multicolumn{2}{|c|}{ Pandemi Sonrası } \\
\hline & Frekans & Yüzde & Frekans & Yüzde \\
\hline Hafta içi & 43 & 11,6 & 82 & 22,2 \\
\hline Hafta sonu & 251 & 67,8 & 44 & 11,9 \\
\hline Hergün & 76 & 20,6 & 244 & 65,9 \\
\hline
\end{tabular}

Tablo 5 incelendiğinde ankete katılan öğrencilerin \%67,8'i pandemi öncesi dönemde haftasonu film izlerken, pandemi sonrası dönemde gündelik hayattaki normallerin pandemi ile değişmesi sonucu öğrencilerin \%65,9’u hergün film izlemeyi tercih etmeyi görülmektedir. Bu oran ile aslında pandeminin etkilerinin de günlük hayata yansımaları görülmektedir.

Öğrencilerin pandemi öncesi ve pandemi sonrası film izlemeyi tercih ettiği saatler sorulmuş ve sonuçlar Tablo 6'da gösterilmiştir.

Tablo 6. Film İzlemeyi Tercih Edilen Saatler

\begin{tabular}{|l|r|r|r|r|}
\hline & \multicolumn{2}{|c|}{ Pandemi Öncesi } & \multicolumn{2}{c|}{ Pandemi Sonrası } \\
\hline Saat Aralı̆̆ı & Frekans & Yüzde & Frekans & Yüzde \\
\hline Sabah (06:00-12:00) & 1 &, 3 & 3 &, 8 \\
\hline Öğlen (13:00-15:00) & 7 & 1,9 & 29 & 7,8 \\
\hline $\begin{array}{l}\text { Akşam üzeri (16:00- } \\
\text { 18:00) }\end{array}$ & 27 & 7,3 & 52 & 14,1 \\
\hline Akşam (19:00-22:00) & $\mathbf{1 9 0}$ & $\mathbf{5 1 , 4}$ & 86 & 23,2 \\
\hline Gece (23:00-03:00) & 145 & 39,1 & $\mathbf{2 0 0}$ & $\mathbf{5 4 , 1}$ \\
\hline
\end{tabular}

Tablo 6 incelendiğinde, pandemi öncesinde öğrencilerin \%51,4'ü akşam saatlerinde film izlemeyi tercih ederken, pandemi sonrası dönemde öğrencilerin \%54,1'inin gece film izlemeyi tercih ettiği görülmektedir. Pandemi sonrası birçok faaliyetin online mecralara taşınması yolda, trafikte vs. geçirilen zamanın da ortadan kalkmasıyla gündelik hayatımızın akışında değişiklikler görülmüştür. Örneğin, artık erkenden kalkıp yolda geçirilen bir zaman dilimi olmadığı için gece daha geç saatlerde de film izlenebilmektedir. Bununla birlikte akşam saati dışında genel olarak her saat diliminde, pandemi öncesine göre pandemi sonrası film izleyen öğrencilerin yüzdesinde artış olduğu görülmektedir.

Tablo 7. Filmi Genellikle Yalnız mı Yoksa Birisi ile Birlikte mi İzlemeyi Tercih Edersiniz?

\begin{tabular}{|r|r|r|r|r|}
\hline & \multicolumn{2}{|c|}{ Pandemi Öncesi } & \multicolumn{2}{c|}{ Pandemi Sonrası } \\
\hline & Frekans & Yüzde & Frekans & Yüzde \\
\hline Yalnız izlerim & $\mathbf{2 5 7}$ & $\mathbf{6 9 , 5}$ & $\mathbf{2 6 7}$ & $\mathbf{7 2 , 2}$ \\
\hline Birisi ile birlikte izlerim & 113 & 30,5 & 103 & 27,8 \\
\hline
\end{tabular}

Tablo 7 incelendiğinde, öğrenciler pandemi öncesinde de pandemi sonrasında da yalnız film izlemeyi tercih etmektedirler. Ancak, pandemi sonrasında yalnız izlemeyi tercih etme oranında artış görülmektedir. 
Öğrencilerin pandemi öncesi ve pandemi sonrası hangi sıklıkla film izledikleri sorulmuş ve sonuçlar Tablo 8'de gösterilmiştir.

Tablo 8. Hangi Sıklıkla Film İzlersiniz?

\begin{tabular}{|l|r|r|r|r|}
\hline & \multicolumn{2}{|c|}{ Pandemi Öncesi } & \multicolumn{2}{c|}{ Pandemi Sonrası } \\
\hline Film İzleme Sıklı̆ı̆ & Frekans & Yüzde & Frekans & Yüzde \\
\hline Her gün & 20 & 5,4 & 78 & 21,1 \\
\hline Haftada 4-6 gün & 34 & 9,2 & $\mathbf{1 1 2}$ & $\mathbf{3 0 , 3}$ \\
\hline Haftada 2-3 gün & $\mathbf{1 3 6}$ & $\mathbf{3 6 , 7}$ & 100 & 27,0 \\
\hline Haftada 1 gün & 97 & 26,2 & 32 & 8,6 \\
\hline 2 haftada 1 gün & 35 & 9,5 & 26 & 7,0 \\
\hline Daha seyrek & 48 & 13,0 & 22 & 6 \\
\hline
\end{tabular}

Tablo 8 incelendiğinde, pandemi öncesinde öğrencilerin \%36,7'si haftada 2-3 gün film izlemeyi tercih ederken, pandemi sonrasında bu oran \%27'ye düşmüş ve haftada 4-6 gün film izleme oranı \%30,3'e yükselmiştir. Pandeminin günlük yaşantıda bireysel aktivitelerin artışına olumlu etkisi olduğu görülmektedir. Öğrencilerde de film izleme aktivesi ve filmi yalnız izleme tercihinde frekansların pandemi öncesine göre artış gösterdiği söylenebilir.

Öğrencilere pandemi öncesi dönemde vizyona giren filmleri en çok nerede izlemeyi tercih ettikleri sorulmuş ve sonuçlar Tablo 9'da gösterilmiştir.

Tablo 9. Pandemi Öncesi Dönemde vizyona giren filmleri en çok nerede izlemeyi tercih ederdiniz?

\begin{tabular}{|l|r|r|}
\hline & Frekans & \multicolumn{2}{|c|}{ Yüzde } \\
\hline Sinema Salonunda & $\mathbf{2 1 9}$ & $\mathbf{5 9 , 2}$ \\
\hline Evde & 151 & 40,8 \\
\hline
\end{tabular}

Tablo 9 incelendiğinde, pandemi öncesi dönemde öğrencilerin \%59,2'si vizyona giren filmleri sinema salonunda izlemeyi tercih etmektedir.

Öğrencilere, pandemi öncesi dönemde vizyona giren filmleri sinema salonunda izlemeyi tercih edenlerin sinemaya gitme sıklıkları sorulmuş ve sonuçlar Tablo 10' da gösterilmiştir (Bu soruya 205 öğrenci cevap vermiştir).

Tablo 10. Pandemi Öncesi Dönemde Sinemaya Gitme Sıklığı

\begin{tabular}{|l|r|r|}
\hline & Frekans & \multicolumn{1}{|c|}{ Yüzde } \\
\hline Haftada birkaç kez & 5 & 2,4 \\
\hline Haftada 1 kez & 22 & 10,7 \\
\hline 2-3 haftada 1 kez & $\mathbf{7 2}$ & $\mathbf{3 5 , 1}$ \\
\hline Ayda 1 kez & 53 & 26 \\
\hline 2 ayda 1 kez & 30 & 14,6 \\
\hline 3-4-5 ayda 1 kez & 18 & 8,8 \\
\hline 6 ayda 1 kez ya da daha az & 5 & 2,4 \\
\hline
\end{tabular}


Tablo 10 incelendiğinde, Pandemi öncesi dönemde, vizyona giren filmleri sinema salonunda izlemeyi tercih eden öğrencilerin \%35,'i 2-3 haftada bir kez sinemaya gitmektedirler.

Öğrencilere pandemi bittikten ve hayat normalleştikten sonra en çok nerede film izlemeyi tercih edecekleri sorulmuş ve sonuçlar Tablo 11'de gösterilmiştir.

Tablo 11. Pandemi bittikten ve hayat normalleştikten sonra en çok nerede film izlemeyi tercih edeceksiniz?

\begin{tabular}{|l|r|r|}
\hline & Frekans & \multicolumn{2}{|c|}{ Yüzde } \\
\hline Sinema Salonunda & & $\mathbf{1 0 7}$ \\
\hline Evde & 98 & $\mathbf{5 2 , 2}$ \\
\hline
\end{tabular}

Tablo 11 incelendiğinde, pandemi öncesi dönemde, vizyona giren filmleri sinema salonunda izlemeyi tercih eden öğrencilerin \%52,2'si hayat normale döndügünde yine sinema solununda film izlemeyi tercih edeceklerini, \%47,8'i evde izlemeyi tercih edeceklerini belirtmişlerdir. Dolayısıyla sinema salonu tercihinde bir azalış söz konusudur. Pandemi bitse de etkilerinin devam edeceği söylenebilir.

Öğrencilere abonelik sistemli video platformlarından hangisine/hangilerine üye oldukları sorulmuş ve sonuçlar Tablo 12'de gösterilmiştir.

Tablo 12. Abonelik sistemli video platformlarından hangisine/hangilerine üyesiniz?

\begin{tabular}{|c|c|c|}
\hline Abonelik sistemli video platformları & Frekans & Yüzde \\
\hline Hiçbiri & 42 & 11,4 \\
\hline Netflix & 306 & 82,7 \\
\hline Puhutv & 74 & 20 \\
\hline BluTV & 70 & 18,9 \\
\hline beIN CONNECT & 70 & 18,9 \\
\hline Turkcell TV Plus & 57 & 15,4 \\
\hline Tivibu & 52 & 14,1 \\
\hline D-Smart GO & 28 & 7,6 \\
\hline Mubi & 16 & 4,3 \\
\hline Filmbox Live & 15 & 4,1 \\
\hline Diğer & 7 & 1,9 \\
\hline
\end{tabular}

Tablo 12 incelendiğinde, Öğrencilerin \%82,7’lik büyük bir çoğunluğu Netflix’e üyedir. Netflix'den sonra sirasiyla Puhutv, Blu tv ve beIN CONNECT platformlarına üyelik söz konusudur.

Öğrencilere abonelik sistemli video platformlarına ne zaman üye oldukları sorulmuş ve sonuçlar Tablo 13'de gösterilmiştir. 
Tablo 13. Abonelik sistemli video platformlarına ne zaman üye oldunuz? (Üyeliği olmayanlar bu soruya cevap vermemiştir)

\begin{tabular}{|c|r|r|}
\hline & Frekans & \multicolumn{2}{|c|}{ Yüzde } \\
\hline Pandemi Öncesi & $\mathbf{2 8 6}$ & $\mathbf{8 7 , 5}$ \\
\hline Pandemi Sonras1 & 41 & 12,5 \\
\hline
\end{tabular}

Tablo 13 incelendiğinde öğrencilerin \%87,5'i pandemi öncesi dönemde abonelik sistemli video platformlarına üye olurken $\% 12,5$ 'i pandemi sonrası dönemde üye olmuşlardır.

Öğrencilere abonelik sistemli video platformlarına pandemi sonrası üye olma nedenleri sorulmuş ve sonuçlar Tablo 14'de gösterilmiştir. (Pandemi sonrası üye olan 41 öğrenciden 37 si cevap vermiştir).

Tablo 14. Abonelik Sistemli Video Platformlarına Pandemi Sonrası Üye Olma Nedenleri

\begin{tabular}{|c|c|c|}
\hline $\begin{array}{l}\text { Abonelik sistemli video platformlarına pandemi sonrası } \\
\text { üye olma nedeni }\end{array}$ & Frekans & Yüzde \\
\hline Serbest zamanımı değerlendirmek & 28 & 75,7 \\
\hline Kontrolün ve zamanın izleyiciye ait olması & 13 & 35,1 \\
\hline İçerik seçimi yapabilmek & 13 & 35,1 \\
\hline Pandemiden dolayı televizyonda dizilerin yer almaması & 6 & 16,2 \\
\hline İçinde bulunduğum ortamdan kaçış & 5 & 13,5 \\
\hline $\begin{array}{l}\text { Türkiye'de ve Dünyada yaşanan gelişmeleri takip etmek } \\
\text { için/Gündemi takip etmek }\end{array}$ & 2 & 5,4 \\
\hline
\end{tabular}

Tablo 14 incelendiğinde abonelik sistemli video platformlarına pandemi sonrası üye olan öğrencilerin \% 75,7'lik büyük bir kısmı serbest zamanlarını değerlendirmek için üye olmuşlardır. Diğer üye olma nedenleri ise, kontrolün ve zamanın izleyiciye ait olması ve içerik seçimi yapabilmek olduğunu belirtmişlerdir. Pandemi ile başlayan yeni normlar ile evde geçirilen gündelik hayatın planlaması ve kontrolü artık kişinin kendi elindedir ve bunu en eğlenceli şekilde planlayıp değerlendirmek üzere reklam vb. dış etkenlerin olmadığı, daha yoğun şekilde ve kısa sürede içerik tüketebildiği abonelik sistemli platformlara üye olup dilediği saat diliminde daha fazla filmi seyrederek değerlendirebildiği söylenebilir.

Öğrencilere kanallara göre film izleme tercihleri sorulmuş ve sonuçlar Tablo 15 'de gösterilmiştir.

Tablo 15. Kanallara Göre Film İzleme Tercihi

\begin{tabular}{|l|r|r|r|r|}
\hline & \multicolumn{2}{|c|}{ Birinci Tercih } & \multicolumn{2}{c|}{ İkinci Tercih } \\
\hline Film Türleri & Frekans & Yüzde & Frekans & Yüzde \\
\hline Netflix & $\mathbf{3 0 4}$ & $\mathbf{8 4 , 7}$ & 0 & 0 \\
\hline YouTube & 20 & 5,6 & $\mathbf{1 3 3}$ & $\mathbf{4 6 , 8}$ \\
\hline Televizyon & 10 & 2,8 & 43 & 15,1 \\
\hline
\end{tabular}




\begin{tabular}{|l|r|r|r|r|}
\hline beIN CONNECT & 3 &, 8 & 22 & 7,7 \\
\hline Tivibu & 3 &, 8 & 16 & 5,6 \\
\hline Puhutv & 3 &, 8 & 11 & 3,9 \\
\hline Mubi & 3 &, 8 & 6 & 2,1 \\
\hline Turkcell TV Plus & 3 &, 8 & 7 & 2,5 \\
\hline BluTV & 2 &, 6 & 21 & 7,4 \\
\hline D-Smart GO & 1 &, 3 & 6 & 2,1 \\
\hline FOXPlay (ücretsiz) & 1 &, 3 & 3 & 1,1 \\
\hline Filmbox Live & 1 &, 3 & 1 &, 4 \\
\hline $\begin{array}{l}\text { Diğer (torrent,internet } \\
\text { siteleri) }\end{array}$ & 5 & 1,4 & 15 & 5,3 \\
\hline
\end{tabular}

Tablo 15 incelendiğinde, Öğrenciler öncelikli olarak Netflix’den film izlemeyi tercih ederken, ikinci seçim olarak YouTube'dan film izlemeyi tercih etmektedirler.

\section{Sonuç}

Sinema, diğer sanat dallarından (müzik, dans, resim gibi) daha çok kültürel kodun taşıyıcısıdır. Dolayısıyla bir toplumu irdelemek için öncellikle bu sanatı ele almak kültürel, sosyal ve siyasal olarak büyük önem arz etmektedir. Sinema toplumunu ve kültürünü önemli ölçüde yansıtmaktadır. Salt bir sanat aracı değil aynı zamanda toplumlara büyük paralar kazandıran büyük bir endüstridir. Küreselleșen dünyada ve film endüstrilerinde yaşanan yükseliş 2000'li yıllardan itibaren günümüze kadar ulaşmıştır.

Özellikle pandemiyle birlikte sinema salonlarından iyice uzaklaşan seyircinin film izleme alışkanlığında alternatif seyir biçimleri yerini almıştır. Bu süreçte gündelik hayatın tamamına yayılan bu deneyim özellikle yeni izleme biçimleri sayesinde kontrolün ve zamanın seyirciye ait olduğu bir süreci beraberinde getirmektedir. Seyircinin dönüşümü, yaşanan Covid-19 salgını sonrasında abonelik sistemli video platformlarına üyelik şeklinde hızlı bir ivme kazanmıştır. 2020'li yıllarda yaşanan Covid-19 pandemi sürecinin gündelik hayatın tamamına yayılan film izleme deneyimini üzerinde değişimin yaşandığı görülmektedir. Günümüzde Nexflix, Puhutv, BluTV, Filmbox Live vb. farklı dijital platformlar ile birlikte sinema salonu seyirci sayısı azaltırken koronavirüs salgını ile sinema salonlarının tamamen kapatılması seyirciyi dijital platformalara bağımlı hale getirdiği düşünülmektedir. İzleme alışkanlıklarımızdaki değişimle birlikte film üretim süreçlerinde de görülen değişim zaman ve mekan sınırlamasını aşarak seyir sürecinin sadece sinema salonlarına bağlı olmadığını göstermektedir. Özellikle yaşanan pandemi döneminde teknolojik üstünlüğü elinde tutan sinema film ve dizi izleme platformlarının da yaygınlaşmasıyla seyircinin izleme alışkanlıklarını dönüşüme uğratmıştır.

Bu noktadan hareketle, çalışma bir vakıf üniversitesinin tüm fakültelerinde eğitim görmekte olan öğrencilere yönelik uygulanmıştır. Bu çalışmada yer alan anket verilerinin sonucu üniversite öğrencilerinin film izleme alışkanlıkları üzerindeki değişimin özellikle pandemi öncesi ve sonrası farklılıklar gösterdiği görülmektedir. 445 anketin analize uygun bulunduğu çalışmada, öğrencilerin \%56'sı kadın, \%44'ü erkektir. Yaş dağılımına bakıldığında üniversite öğrencilerine anket uygulandığından öğrencilerin \%86,3'ü 18-24 yaş aralığında bulunmaktadır. 
Tablo 3 ve Tablo 4 incelendiğinde öğrencilerin pandemi öncesinde ve sonrasında en çok seyretmeyi sevdiği üç film türü sorulduğunda öğrenciler pandemi dönemi öncesinde ve sonrasında birinci tercih olarak aksiyon filmlerini ve dram filmlerini tercih etmektedir. İkinci tercih olarak pandemi öncesinde, macera ve suç konulu filmler tercih ederken, pandemi sonrasında suç yerine romantik filmleri tercih etmişlerdir. Üçüncü tercih olarak ise, her iki dönemde de gerilim ve komedi filmleri bulunmaktadır.

Özellikle Tablo 5'de görüldüğü gibi ankete katılan öğrencilerin çoğunun pandemi öncesi dönemde haftasonu film izlediği ancak pandemi sonrası dönemde gündelik hayattaki normallerin değişmesiyle hergün film izlemeyi tercih ettikleri görülmektedir. $\mathrm{Bu}$ oran ile aslında pandeminin etkileriyle film izleme eylemine ayırdı̆̆ımız ciddi bir zaman dilimi olduğu da görülmektedir.

Tablo 6'ya baktığımızda pandemi öncesinde öğrencilerin genelde akşam saatlerinde film izlemeyi tercih ettiği görülürken, pandemi sonrası dönemde öğrencilerin gece film izlemeyi tercih ettiği görülmektedir. Pandemi sonrası birçok faaliyetin online mecralara taşınması, trafikte vs. geçirilen zamanın da ortadan kalkmasıyla gündelik hayatımızın akışında değişiklikler görülmüştür. Örneğin, üniversitelerin pandemi sürecinde online eğitime devam etmesiyle özellikle gençlerin uyku düzenlerindeki düzensizliklerin zaman kavramını ortadan kaldırdığı düşünülmektedir.

Pandemi öncesinde öğrenciler haftada 2-3 gün film izlemeyi tercih ederken pandemi sonrasında bu oran haftada 4-6 güne çıkmaktadır. Pandemi öncesi dönemde, vizyona giren filmleri sinema salonunda izlemeyi tercih eden öğrencilerin geneli hayat normale döndüğünde yine sinema solununda film izlemeyi tercih edeceklerini, diğerlerinin ise evde film izlemeyi tercih edeceği sonucu çıkmaktadır.

$\mathrm{Bu}$ noktadan hareketle, gelişen teknoloji ile birlikte gündelik hayat pratiklerimizin hızla değiştiği görülmektedir. Değişen seyir biçimimizle modern bireyin film izleme alışkanlıkları değiştirmeye başlamıştır. 2020 yılı itibariyle dünya çapında büyük bir salgına neden olan Covid-19'un etkisiyle aslında bu süreçte ciddi bir dönüşümün yaşandığ düşünülmektedir. Tüm dünyanın evlerine kapandığı pandemi sürecinde dijitalleşen film izleme pratikleri tüketim kültüründe kendine sağlam bir yer edinmiştir.

\section{Kaynaklar}

Abanoz, E. (2013). “Bilgi Toplumda Yöndeşmenin Haber Üretimi Süreci Üzerindeki Etkisi: Haber Ajansı Çalışanları Üzerine Bir Araştırma”. İstanbul: Marmara Üniversitesi Sosyal Bilimler Enstitüsü, Yüksek Lisans Tezi.

Aktaş, C. (2014). QR Kodlar ve İletişim Teknolojisinin Hibritleşmesi. İstanbul: Kalkedon Yayınları.

Aydın, Ş. O. (2019). Yeni İzleme Biçimleri ve Netflix Içcrikleri: Ritzer’in Mcdonaldlaşma Tezi Ekseninde Bir Değerlendirme. Uluslararası Sosyal Araştırmalar Dergisi, Cilt: 12, Say1: 63, s: 1167-1172. 
Çă̆ıl F. ve Kara M. F. (2019). Dijital Dönüşüm Bağlamında Türkiye’de Dizi Sektörü ve Geleceği. Artuklu Sanat ve Beşeri Bilimler Dergisi, Sayı:1, s: 8-18.

Kantar Media, Mediacom Medya Analizi ve Tüketici Davranışları Raporu, Nisan 2020. 2020.

Kantar Media, Mediacom Medya Analizi ve Tüketici Davranışları Raporu, Mayıs

Künüçen, H. ve Olguntürk, K. (2016). "Yeni Film Dili: Amatör Video”, Şentürk, R. (ed.), Dijital Sinema Kuramdan Tekniğe, İstanbul: İnsan Yayınları.

Manovich, L. (2001). The Language of New Media, Massachusetts: The MIT Press.

Oğuzhan, Ö. (2015). "Ya Sinema Seyirci Kalırsa”, Bayrakdar D. (ed.), 11. Türk Film Araştırmalarında Yeni Yönelimler, İstanbul: Bağlam Yayıncılık, s: 210-223.

Ormanl1, O. (2012). Dijitalleşme ve Türk Sinemasl, The Turkish Online Journal of Design, Art and Communication, Vol: 2, No: 2, s: 32-38.

Özdemir, Y. A., Şahin Tekin, S. T., ve Esin, A. (2019). Çözümlü Örneklerle Örnekleme Yöntemlerine Giriş. Ankara: Seçkin Kitapevi.

Özden H., Turanlı M., Başar Ö. D., Kalkan S. B. ve Erişlik K. (2020), Koronavirüs Pandemisi Raporu, İstanbul Ticaret Üniversitesi, İstatistik Bölümü.

Randolph, M. (2020). Bu İş Asla Tutmaz Netflix. Çev. M. Yılmaz, İstanbul: Konu Fikir Sanat Edebiyat Yapım ve Dağıtım.

Sunal, G. (2016). Sanal Gerçeklik ve Dijital Sinemanın Olanakları. İnönü Üniversitesi İletişim Fakültesi Elektronik Dergisi, Cilt:1, Sayı:2, s: 294-309.

Şentürk R. (2017). Türkiye'de Film Endüstrisi (2011-2015), İstanbul: İstanbul Ticaret Odası (İTO)/İstanbul Düşünce Akademisi.

Şentürk R., Sivas A., Sunal G. ve Y1lmaz R. H. (2014). Türk Sinemasının Durum Analizi (2005-2010). İstanbul: İstanbul Ticaret Odas1.

Şentürk, R. (2016). Sinemanın Dramı, Rıdvan Şentürk (ed.), Dijital Sinema Kuramdan Tekniğe, İstanbul: İnsan Yayınları.

\section{Elektronik Kaynaklar}

URL-1 https://journo.com.tr/netflix-buraya-nasil-geldi, (Erişim Tarihi: 10.09.2020)

URL-2 https://www.ted.com/talks/reed hastings how netflix changed entertainment_and_where_it_s_headed (Erişī̄ Tarihi: 01.11.2020) 